\title{
Cytogenetic evolution of human ovarian cell lines associated with chemoresistance and loss of tumorigenicity
}

\author{
Stéphanie Struski ${ }^{a}$, Martine Doco-Fenzy ${ }^{b}$, Michael Koehler $^{\mathrm{c}}$, Ilse Chudoba ${ }^{\mathrm{d}}$, Francis Levy ${ }^{\mathrm{e}}$, \\ Linda Masson ${ }^{\mathrm{b}}$, Nicole Michel ${ }^{\mathrm{b}}$, Evelyne Ulrich ${ }^{\mathrm{b}}$, Nadine Gruson ${ }^{\mathrm{b}}$, Jean Bénard ${ }^{\mathrm{f}}$, Gérard Potron ${ }^{\mathrm{a}}$ and \\ Pascale Cornillet-Lefebvre ${ }^{\mathrm{a}, *}$ \\ ${ }^{a}$ Laboratory of Hematology, Robert Debré Hospital and Medical Faculty \\ (UPRES EA 20-70-IFR 53 Biomolecules), 51100 Reims, France \\ ${ }^{\mathrm{b}}$ Laboratory of Cytogenetic, Maison Blanche Hospital, 51100 Reims, France \\ ${ }^{\mathrm{c}}$ ASI GmbH, 68309 Mannheim, Germany \\ ${ }^{\mathrm{d}}$ MetaSystems, 68804 Altlussheim, Germany \\ e Polytec-PI, Electro-optics Division, 93694 Pantin, France \\ ${ }^{\mathrm{f}}$ Gustave Roussy Institute, 94800 Villejuif, France
}

Received 14 October 2002

Accepted 20 January 2003

\begin{abstract}
In order to identify genomic changes associated with a resistant phenotype acquisition, we used comparative genomic hybridization $(\mathrm{CGH})$ to compare a human ovarian cell line, Igrov1, and four derived subcell lines, resistant to vincristine and presenting a reversion of malignant properties. Multicolor FISH (Multiplex-FISH and Spectral Karyotype) and conventional FISH are also used to elucidate the karyotype of parental cell line. The drug-resistant subcell lines displayed many chromosomal abnormalities suggesting the implication of different pathways leading to a multidrug resistance phenotype. However, these cell lines shared two common rearrangements: an unbalanced translocation $\operatorname{der}(8) \mathrm{t}(8 ; 13)(\mathrm{p} 22 ; \mathrm{q}$ ?) and a deletion of the 11p. These chromosomal imbalances could reflected the acquisition of the chemoresistance $(\operatorname{der}(8))$ or the loss of tumorigenicity properties $(\operatorname{del}(11 \mathrm{p}))$.

Colour figure can be viewed on http://www.esacp.org/acp/2003/25-3/struski.htm
\end{abstract}

\section{Introduction}

The development of resistance to chemotherapeutic agents is a limiting factor in the management of neoplastic diseases and results in treatment failure.

The multidrug-resistance (MDR) is a cross-resistance toward several cytostatic agents showing homology of structure or mechanism of action [25]. In vitro studies on cell lines provide interesting models for the characterization of the biologic mechanisms mediating this phenomenon. Several multidrug resistance mecha-

\footnotetext{
${ }^{*}$ Corresponding author. Pascale Cornillet-Lefebvre, Laboratoire d'Hématologie, Hôpital Robert Debré - CHU Reims, 51092 Reims cedex, France. Tel.: +333 267 87789; Fax: +333 267 88171; E-mail: plefebvre@chu-reims.fr.
}

nisms have been proposed, e.g., increased drug efflux, enhanced intracellular drug detoxification, alterations in nuclear targets, modifications of DNA repair systems, and apoptotic ways [1,21,25].

Because of complexity and heterogeneity of tumors and cell lines karyotypes, identification of recurrent and specific chromosomal changes may be facilitated by comparative genomic hybridization (CGH) [12]. Indeed, several studies have used $\mathrm{CGH}$ as a tool to identify loci associated with chemoresistance $[9,15,16,18$, 22,23,26,27,30].

We studied a previously described human ovarian adenocarcinoma cell line, Igrov1, and its derived subcell lines, which acquired a vincristine-resistance and a loss of tumorigenicity properties [2]. The parental 
Igrov-1 karyotype was resolved by a "multi-technique approach": karyotype, classical FISH, multiplex FISH (M-FISH), spectral karyotyping (SKY), and CGH. The chromosomal study of interest genes in the resistant subcell lines was performed by a CGH approach.

\section{Materials and methods}

\subsection{Cell line}

The human ovarian adenocarcinoma cell line, Igrov1, was obtained from a patient treated at the Gustave Roussy Institute with her previous consent (Jean Bénard, Villejuif, France) [3]. Igrov1 was cultured in Dulbecco's modified Eagle's medium nutrient mixture F-12 Ham (Sigma, Saint Louis, USA) supplemented with $20 \%$ fetal calf serum (Boehringer Mannheim, Meylan, France). Four resistant sublines, derived from the parental Igrov1 cell line and obtained by increasing concentrations to vincristine (VCR), have been previously described [2,28,29]. Briefly, the cells were exposed continuously or discontinuously (for $24 \mathrm{~h}$ at each passage during the exponential phase of growth) to vincristine. Discontinuous exposure gave rise to a OV1/VCR subline resistant to a $2 \mu \mathrm{g} / \mathrm{ml}$ for $24 \mathrm{~h}$ (OV1/VCR.discont.) while continuous exposure led to a OV1/VCR subline resistant to $0.2 \mu \mathrm{g} / \mathrm{ml}$ (OV1/VCR.cont). Two sublines derived from both VCR resistant cells were serially subcultured for more than 100 generations in a drug free culture medium to give OV1/VCR.cont.st. and OV1/VCR.discont.st. (st. for starvation). We precise that the sublines derived from the same cell.

\subsection{Karyotype}

R-banding karyotype was obtained as previously described for cytogenetic techniques [6]. Karyotypic abnormalities were described according to the International System for Human Cytogenetic Nomenclature [20].

\subsection{SKY analysis}

The SKY hybridization and analysis protocol were realized according to instructions and in collaboration with Applied Spectral Imaging (SKYPaint mixture, Migdal HaEmek, Israel) to study Igrov1 cell line. Spectral images were captured with a SD200 SpectraCube system (Applied Spectral Imaging) mounted on a Zeiss Axioplan-2 microscope (Carl-Zeiss-Jena, Germany). A mathematical classification algorithm was applied to discriminate differentially labeled chromosomes based on their emission spectrum. The SkyView automatic spectral karyotyping software combined the Dapi-banded image with multicolor SKY information and chromosome ideograms.

\subsection{M-FISH analysis}

The M-FISH protocol and the analysis were realized in collaboration with MetaSystems (24Xcyte, Altlussheim, Germany) to explore the Igrov1 cell line. Separate fluorochrome images were captured using a fluorescence microscope (Axioplan-2, Zeiss) equipped with a motorized filter wheel and specific filter sets for Dapi, DEAC, FITC, Spectrum Orange, Texas Red and Cy5 (Chroma Technology, USA). The resultant images were analyzed using the Isis/M-FISH software (MetaSystems).

\subsection{CGH analysis}

CGH was performed according to the method described by Kallioniemi et al. [11] and Lichter et al. [19]. The parental cell line, Igrov1 DNA, was labeled, by nick translation, with Texas Red-dUTP (Spectrum Red direct labeled total human genomic DNA, Vysis, Downers Grove, USA) and the four resistant cell lines, OV1/VCR DNAs, were labeled with FITCdUTP (Spectrum Green, Vysis). For image acquisition, we used a fluorescence DMRB microscope (Leica, Switzerland) with 3 separate band pass filters (Leica) for Dapi, FITC and Texas Red. The data from all individual fluorescence ratios (FR) were calculated by an appropriate software (ISIS: option CGH: MetaSystems, Altlussheim, Germany) and, using standard reference intervals $[13,14]$, under- or over-represented chromosomal regions were identified.

\subsection{FISH analysis}

FISH was carried out using telomere specific probes for the chromosomes 3 (3p: D3S4559 and 3q: D3S1272) and 18 (18p: 52M11 and 18q: D18S1390) (Chromoprobe-T, Cytocell, UK), and two alpha satellite specific probes for the chromosomes X (DXZ1) and 18 (D18Z1) (Oncor, Gaithersburg, MD). Whole chromosome painting probes (WCP) have been also used (Cambio, Cambridge, UK; Oncor). Probes were labeled with digoxigenin or biotin and revealed by 


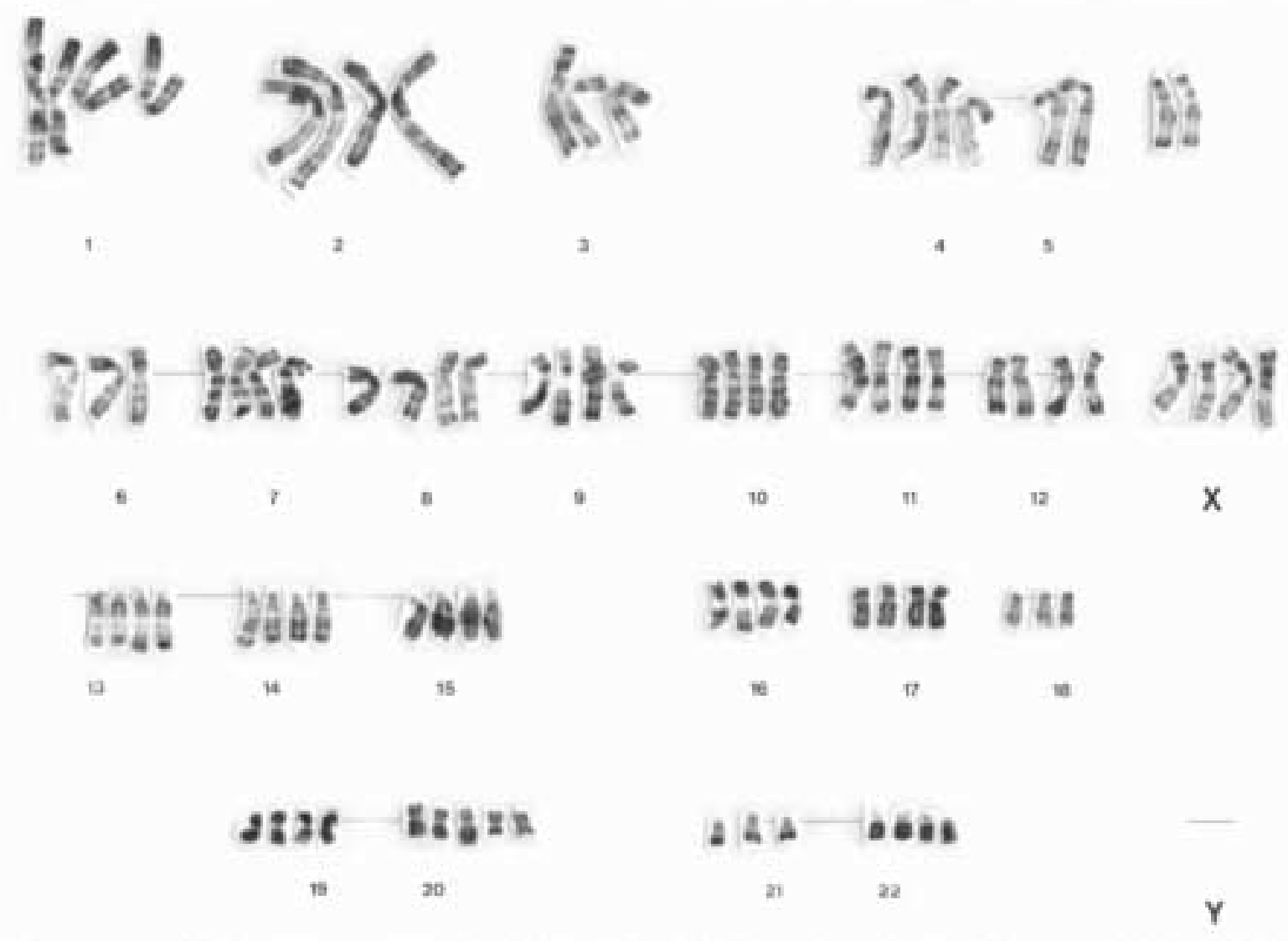

Fig. 1. R-banded karyotype of a representative near-tetraploid metaphase of Igrov1. The karyotype was interpreted as 85-92,XXX,der(X)t(X;18) $(\mathrm{p} 11 ; \mathrm{p} 11), \mathrm{t}(2 ; 5)(\mathrm{q} 3 ? 6 ; \mathrm{q} 2 ? 3) \times 2, \operatorname{der}(2) \mathrm{t}(2 ; 20)(\mathrm{q} 3 ? 7 ; ?),-3, \operatorname{der}(3) \operatorname{inv}(3)(\mathrm{p} 13 \mathrm{p} 25) \operatorname{del}(3)(\mathrm{p} 14) \mathrm{x} 2,-6, ? \operatorname{der}(7)(\mathrm{p} 22), \operatorname{der}(9) \mathrm{t}(9 ; 18)(\mathrm{q} 34 ; \mathrm{q} 2$ ?2) x2, $\operatorname{der}(13) \mathrm{t}(13 ; 20)(\mathrm{q} 34 ; \mathrm{q} 12) \times 2,-18,+20, \operatorname{del}(20)(\mathrm{q} 12) \times 2,-21$.

FITC or CY3, respectively. Hybridizations were performed according to manufacturer's protocol and the slides were counterstained with Dapi. Metaphases were analyzed under fluorescence DMRB microscope (Leica).

\section{Results}

Colour figure can be viewed on http://www.esacp. org/acp/2003/25-3/struski.htm

\subsection{Characterization of the Igrov1 parental cell line}

\subsubsection{Karyotype}

Igrov1 karyotype has been previously established in 1985 [3]. We observed that the modal chromosome number was near-tetraploid and the karyotype was first interpreted as $85-92, \mathrm{XXX}, \operatorname{del}(\mathrm{X})(\mathrm{p} 21 \mathrm{p} 22)$, $\mathrm{t}(2 ; 5)(\mathrm{q} 3$ ? 6; q2 ? 3) x2, - 3, der(3)inv(3)(p13p25)del(3) (p14)x2,-6,?der(7)(p22), $\operatorname{add}(13)(\mathrm{q} 34) \times 2,-18,+20$, $\operatorname{del}(20)(\mathrm{q} 12) \times 2,-21$ [cp25] (Fig. 1).

We precise that all cell lines have been frozen in 1985 and defrosted for this work. So, there is no karyotypic evolution between the two studies.

\subsubsection{SKY and M-FISH}

We have had the opportunity to compare SKY and M-FISH at the time of a demonstration. So, we have analyzed the parental cell line, but we have not had the occasion to explore the sub-lines.

The both methods, realized onto Igrov1, confirmed the translocation $\mathrm{t}(2 ; 5)$ as well as the loss of one copy of the chromosomes 3, 6, 18 and 21, and the pentasomy of the chromosome 20. SKY and M-FISH identified the $\operatorname{add}(13)$ as a translocation $\operatorname{der}(13) \mathrm{t}(13 ; 20)$. They also revealed three others unsuspected translocations: $\operatorname{der}(2) \mathrm{t}(2 ; 20), \operatorname{der}(9) \mathrm{t}(9 ; 18)$ and $\operatorname{der}(\mathrm{X}) \mathrm{t}(\mathrm{X} ; 18)$. 


\subsection{3. $\mathrm{CGH}$}

The CGH hybridization of a green-labeled normal DNA with the red-labeled Igrov1 DNA, revealed losses of the whole chromosomes 3, 6 and 21, and loss of the q-arm of chromosome 18. Gain of chromosome 20 was also detected. Only the partial loss of chromosome 18 was unsuspected at the cytogenetic level.

\subsubsection{FISH}

The 18 and $\mathrm{X}$ alpha satellite probes hybridized the centromeres of the normal chromosomes 18 and chromosomes $\mathrm{X}$, respectively. The $\operatorname{der}(\mathrm{X}) \mathrm{t}(\mathrm{X} ; 18)$ was hybridized by the $\mathrm{X}$ alpha satellite probe. The q-telomere specific probe of chromosome 18 hybridized to the two $\operatorname{der}(9)$ and to one chromosome 18 . The 18 p-telomere specific probe hybridized to the three chromosomes 18 and to the $\operatorname{der}(\mathrm{X})$.

The telomere specific probe of chromosome 3 hybridized to the $\mathrm{p}$ - and the q-telomeres of the normal and the two der(3) chromosomes.

\subsubsection{Revised karyotype}

Thanks to the CGH, SKY and M-FISH results, refined by FISH analysis, we observed more rearrangements than those observed on karyotype. The revised Igrov1 karyotype included the translocations $t(X ; 18)$, $\mathrm{t}(2 ; 20), \mathrm{t}(9 ; 18)$ and $\mathrm{t}(13 ; 20)$, and it was finally interpreted as $85-92, \mathrm{XXX}, \operatorname{der}(\mathrm{X}) \mathrm{t}(\mathrm{X} ; 18)(\mathrm{p} 11 ; \mathrm{p} 11), \mathrm{t}(2 ; 5)$ (q3?6;q2?3)x2, der(2)t(2;20)(q3?7;?),-3, der(3) inv(3) (p13p25) del(3) (p14)x2,-6,?der(7)(p22),der(9)t(9;18) (q34;q2?2) x2, der(13)t(13;20) (q34;q12)x2,-18,+20, $\operatorname{del}(20)(q 12) x 2,-21$ [cp25].

The karyotype including FISH and $\mathrm{CGH}$ results was: $85-92, \mathrm{XXX}, \operatorname{der}(\mathrm{X}) \mathrm{t}(\mathrm{X} ; 18)(\mathrm{p} 11 ; \mathrm{p} 11)$. Ish $\operatorname{der}(\mathrm{X})$ $(\mathrm{wcpX}+, \mathrm{wcp} 18+, \mathrm{DXZ1+}, 52 \mathrm{M} 11+), \mathrm{t}(2 ; 5)$ (q3?6; $\mathrm{q} 2$ ?3)x2. ish $\mathrm{t}(2 ; 5)(\mathrm{wcp} 2+$, wcp5+; wcp5+, wcp2+) $\mathrm{x} 2, \operatorname{der}(2) \mathrm{t}(2 ; 20)(\mathrm{q} 3 ? 7 ; ?)$. ish $\operatorname{der}(2)(\mathrm{wcp} 2+, \mathrm{wcp} 20+)$, -3 . ish3(wcp3x3). rev ish $\operatorname{dim}(3), \operatorname{der}(3) \operatorname{inv}(3)$ (p13p25)del(3)(p14)x2.ish der(3)(wcp3+, D3S4559+, D3S1272+)x2, -6. ish 6(wcp6x3). rev ish $\operatorname{dim}(6)$, ?der(7)(p22). ish der(7)(wcp7+), der(9)t(9;18) (q34; q2?2)x2. ish $\operatorname{der}(9)(w c p 9+$, wcp $18+$, D18S1390+)x2, $\operatorname{der}(13) \mathrm{t}(13 ; 20) \quad(\mathrm{q} 34 ; \mathrm{q} 12) \mathrm{x} 2$. ish $\operatorname{der}(13)(\mathrm{wcp} 13+$, wcp20+)x2, - 18. ish18(wcp18x3, D18Z1x3, $52 \mathrm{M} 11 \times 3, \mathrm{D} 18 \mathrm{~S} 1390 \mathrm{x} 1)$. rev ish $\operatorname{dim}(18 \mathrm{q}),+20$. ish20 (wcp20x5). rev ish enh(20), $\operatorname{del}(20)(\mathrm{q} 12) \times 2$. ish $\operatorname{del}(20)$ (wcp20+)x2, -21. ish21(wcp21x3). rev ish $\operatorname{dim}(21)$.

\subsection{Characterization of the vincristine-resistant cell lines}

\subsubsection{Cell lines}

Bénard et al. [2] and Teyssier et al. [28,29] have previously reported the characteristics of the Igrov1- derivated sublines (OV1/VCR). The four OV1/VCR have been described as expressing a multidrug-resistant phenotype, associated with an overexpression of the MDRl gene, without amplification of the locus. The sublines also displayed a typical reversion of in vivo and in vitro malignant properties.

All results and characteristics of OV1/VCR sublines are summarized in Table 1.

\subsubsection{Karyotypes}

Karyotypes of the four OV1/VCR cell lines presented common abnormalities to the parental cell line Igrov1, as t(2;5), der(3), $-6, \operatorname{del}(20)$ and -21 . The four sublines also displayed differences compared Igrov1 as losses, gains and supplementary rearrangements. These karyotypes being complex, they were difficult to interpret (Table 1). However, we identified a $\operatorname{der}(8) \mathrm{t}(8 ; 13)$.

\subsubsection{FISH}

FISH analysis allowed to observed loss of $\operatorname{der}(\mathrm{X})$ $\mathrm{t}(\mathrm{X} ; 18), \mathrm{t}(2 ; 20)$, and one copy of $\operatorname{der}(9) \mathrm{t}(9 ; 18)$, in the four sublines, except for OV1/VCR.discont.st. which lost the two der(9). The two der(13)t $(13 ; 20)$ were conserved in both OV1/VCR.cont.

Two chromosomal rearrangements were common to the four sublines. We observed a deletion of the $11 \mathrm{p}$ arm in OV1/VCRcont.st., and in both OV1/VCR.discont. The OV1/VCR.cont. cell line presented an unbalanced translocation $\operatorname{der}(1) \mathrm{t}(1 ; 11)(\mathrm{p} 3$ ?5;p12). We also confirmed the $\operatorname{der}(8) \mathrm{t}(8 ; 13)(\mathrm{p} 22 ; ?)$, observed in the karyotype, in the four OV1/VCR lines (Fig. 2).

\subsection{4. $\mathrm{CGH}$}

CGH hybridizations of a red-labeled normal DNA with green-labeled OV1/VCR DNA, and CGH hybridizations of red-labeled Igrov1 DNA with greenlabeled OV1/VCR DNA, supplied supplementary informations on the chromosomal changes associated to each drug-resistant cell line (Table 1).

OV1/VCR.cont. and OV1/VCR.cont.st. cell lines presented common unbalances: losses of 5, 13p13q21.3 and 14, and gains of 7 and 8. OV1/VCR.cont. showed gain of chromosome 1 , and OV1/VCR.cont.st., gain of chromosome 12 and loss of 11 p region.

OV1/VCR.discont. and OV1/VCR.discont.st. cell lines shared losses of 4, 9, 10, 11p, 13p13-q21.3, 14, and gains of 1p21-q44 and 7. OV1/VCR.discont. displayed loss of chromosome 2 and gain of 15q22-q26. OV1/VCR.discont.st. showed gains of chromosome 8 and $18 \mathrm{q} 11-\mathrm{q} 21.1$. 
Table 1

Karyotype, CGH and FISH results of OV1/VCR sublines. The cellular properties and chromosomal changes compared to Igrov1 are presented. "no" means absence. The gray areas and the bold types mean that the chromosomal abnormality was conserved (compared to Igrov1 cell line)

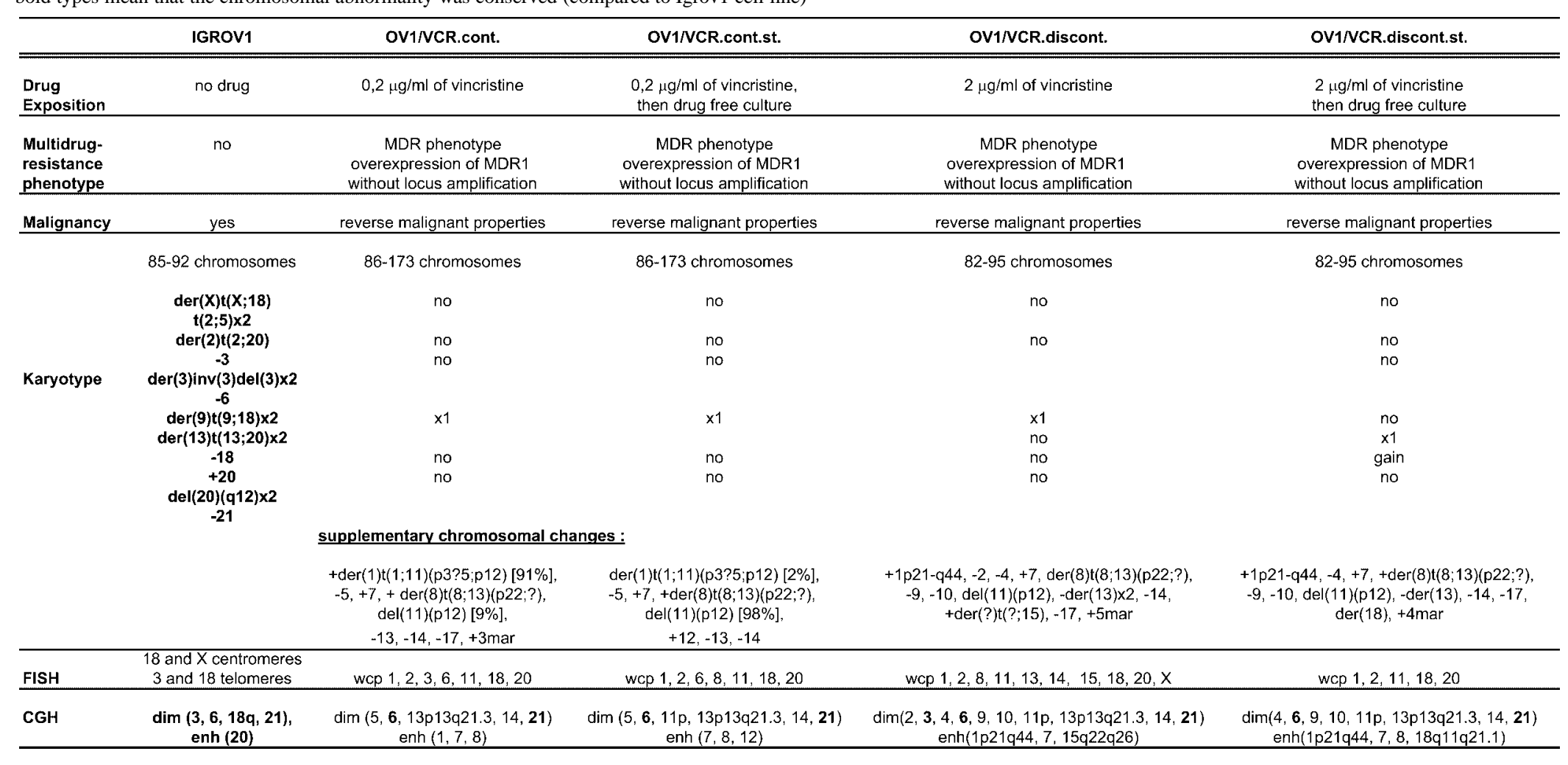




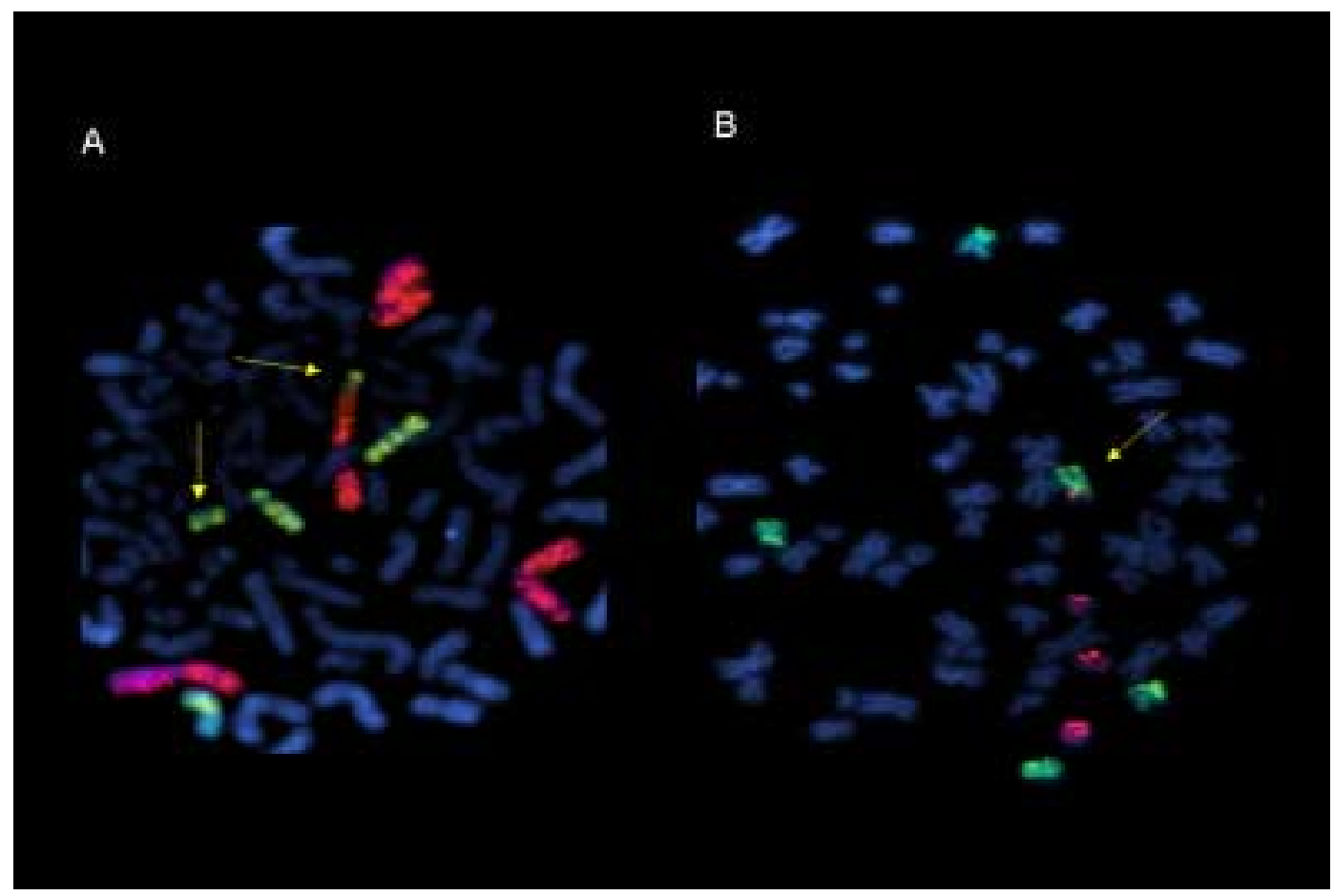

Fig. 2. Partial FISH results on the OV1/VCR cell lines. Hybridizations with WCP1 and WCP11 probes are shown, in red and green respectively, on the OV1/VCR.cont. cell line show the $\operatorname{der}(1) \mathrm{t}(1 ; 11)$ (arrow) (A). The $\operatorname{der}(8) \mathrm{t}(8 ; 13)$ is also presented (B) with hybridization of WCP8 (green) and WCP13 (red) probes. This figure can be viewed on http://www.esacp.org/acp/2003/25-3/struski.htm.

\section{Discussion}

\subsection{Characterization of the Igrov1 parental cell line}

The 24-color FISH methods, M-FISH and SKY, allowed to identify complex and cryptic translocations in a tumor karyotype, by the pattern of color distribution along aberrant chromosomes. The both methods have presented the same sensibility in this study. The value of the CGH has been to estimate the unbalanced or balanced nature of the regions implicated in the chromosomal rearrangements. In this present study, CGH discovered loss of the q-arm of chromosome 18 (in the Igrov1 genome), this imbalance was impossible to guess without this technique. Finally, classical FISH provided precision on concerned regions.

Thus, this study illustrates the complementarity of three approaches of hybridizations in the description of a highly abnormal karyotype. These analysis help to give a more comprehensive analysis of the types of rearrangements, which were present in an aberrant genome, the identity of the chromosomes involved and the specific chromosomal regions of net gain or loss.

\subsection{Characterization of the drug-resistant cell lines, OVINCR}

An understanding of the genetic mechanisms that underlie tumor cell sensitivity and resistance to chemotherapeutic agents is important from a biological as well as clinical standpoint. Previous reports have demonstrated the potential use of the CGH in the detection of regions of the genome implicated in chemoresistance $[9,15,16,18,22,23,26,27,30]$.

Igrov1 cells were induced to become resistant in vitro to vincristine (VCR) by continuous and discontinuous stepwise exposure to the drug. The resultant resistant sublines, OV1/VCR, presented two major characteristics: the acquisition of a MDR phenotype and a marked loss of tumorigenicity properties.

OV1/VCR drug-resistant cell lines displayed a larger number of chromosomal abnormalities. The mechanism of drug resistance in ovarian cancer is multifactor, and accumulation of multiple genetic changes suggests implication of different pathways leading to chemoresistance acquisition $[5,16]$. However, besides the chromosomal markers of Igrov1, the resistant sublines revealed two common cytogenetic rearrangements: an 
unbalanced translocation $\operatorname{der}(8) \mathrm{t}(8 ; 13)(\mathrm{p} 22 ; \mathrm{q}$ ?) and a deletion of the short arm of one chromosome 11 , in OV1/VCR.cont.st. and in both OV1/VCR.discont. cell lines, the OV1/VCR.cont. presenting an unbalanced translocation der(1)t $(1 ; 11)(\mathrm{p} 3 ? 5 ; \mathrm{p} 12)$.

Previous studies $[7,24]$ presented a correlation between tumorigenic phenotypes and region $11 \mathrm{p}$, suggesting that this chromosome carries a gene that controls tumorigenic expression. Horikawa et al. [10] observed in D98-OR cell line that the loss of one chromosome 11 with the duplication of another is associated with a reduced tumorigenicity in nude mice. Coleman et al. [4] mapped a locus within chromosome 11p11.2p12 that suppresses the tumorigenic potential of some rat liver tumor cell lines. Wilms tumor 1 gene (WT1) may be implicated. Hill et al. [8] presented a loss of tumorigenicity in a methotrexate-resistant CEM cell line. This subline displayed a complex $\mathrm{t}(11 ; 22)$, involving $11 \mathrm{p} 14$, suggesting the presence of a gene responsible of the loss of tumorigenicity.

The der(8)t $(8 ; 13)$ present in the four resistant cell lines could also attest of a common property. The chromosomal regions must be more explored and determinated to permit an identification of implicated genes. However, we can precise that chromosome 13 contains some genes of which the function has been already described in chemoresistance acquisition: the retinoblastoma 1 gene (RB1, 13q14.1-14.2) and the breast cancer 2 gene (BRCA2, 13q12.3), both tumor suppressor genes; the thioredoxin-dependent peroxide reductase gene (TDPX1, 13q12), antioxidant gene [16]; the MOAT-B gene (13q32) belonging to ATP-binding cassette subfamily [17].

The 8 p22 region contains a putative tumor suppressor gene, LZTS1, and tumor necrosis factor receptor superfamily members (TRAILR1, TRAILR2, TRAILR3 and TRAILR4), mediating or inhibiting apoptosis way.

In summary, we present evidence that some cell lines could be drug-resistant and display a loss of malignancy characteristics, these both mechanisms seem to be independent. The implication of genes on chromosomes 8,11 and 13, should be more explored by complementary molecular studies, such as quantitative PCR or CGH DNA arrays.

\section{References}

[1] L.G. Baggetto, Non-P-glycoprotein novel proteins involved in human cancer multidrug resistance, Bull. Cancer 84 (1997), 385-390.
[2] J. Bénard, J. Da Silva, J.R. Teyssier and G. Riou, Overexpression of MDR1 gene with no DNA amplification in a multiple-drug-resistant human ovarian carcinoma cell line, Int. J. Cancer 43 (1989), 471-477.

[3] J. Bénard, J. Da Silva, M.C. De Blois, P. Boyer, P. Duvillard, E. Chiric and G. Riou, Characterization of a human ovarian adenocarcinoma line, IGROV1, in tissue culture and in nude mice, Cancer Res. 45 (1985), 4970-4979.

[4] W.B. Coleman, S.L. Ricketts, K.M. Borchert, S.C. Presnell, G.L. Esch, K.D. McCullough, B.E. Weissman, G.J. Smith and J.W. Grisham, Induction of rat WT1 gene expression correlates with human chromosome 11p11.2-p12-mediated suppression of tumorigenicity in rat liver epithelial tumor cell lines, Int. J. Oncol. 14 (1999), 957-963.

[5] M.K. Dodson, L.C. Hartmann, W.A. Cliby, K.A. DeLacey, G.L. Keeney, S.R. Ritland, J.Q. Su, K.C. Podratz and R.B. Jenkins, Comparison of loss of heterozygosity patterns in invasive low-grade and high-grade epithelial ovarian carcinomas, Cancer Res. 53 (1993), 4456-4460.

[6] B. Dutrillaux and J. Lejeune, A new technic of analysis of the human karyotype, CR Acad. Sci. Hebd. Seances Acad. Sci. D 272 (1971), 2638-2640.

[7] G.M. Hampton, L.A. Penny, R.N. Baergen, A. Larson, C. Brewer, S. Liao, R.M. Busby-Earle, A.W. Williams, C.M. Steel, C.C. Bird, E.J. Stanbridge and G.A. Evans, Loss of heterozygosity in cervical carcinoma: subchromosomal localization of a putative tumor-suppressor gene to chromosome 11q22-q24, Proc. Natl. Acad. Sci. USA 91 (1994), 6953-6957.

[8] A.B. Hill, J.M. Trent, F.H. Thompson, M.K. Danks and W.T. Beck, Loss of tumorigenicity in a methotrexate-resistant human leukemia cell line, Cancer Genet. Cytogenet. 70 (1993), 48-55.

[9] M. Hirai, S. Yoshida, H. Kashiwagi, T. Kawamura, T. Ishikawa, M. Kaneko, H. Ohkawa, A. Nakagawara, M. Miwa and K. Uchida, 1q23 gain is associated with progressive neuroblastoma resistant to aggressive treatment, Genes Chromosomes Cancer 25 (1999), 261-269.

[10] I. Horikawa, A. Okamoto, J. Yokota and M. Oshimura, Genetic heterogeneity of chromosome 11 associated with tumorigenicity in HeLa D98-OR cells, Cancer Genet. Cytogenet. 85 (1995), 97-100.

[11] O.P. Kallioniemi, A. Kallioniemi, J. Piper, J. Isola, F.M. Waldman, J.W. Gray and D. Pinkel, Optimizing comparative genomic hybridization for analysis of DNA sequence copy number changes in solid tumors, Genes Chromosomes Cancer 10 (1994), 231-243.

[12] A. Kallioniemi, O.P. Kallioniemi, D. Sudar, D. Rutovitz, J.W. Gray, F. Waldman and D. Pinkel, Comparative genomic hybridization for molecular cytogenetic analysis of solid tumors, Science 258 (1992), 818-821.

[13] M. Kirchhoff, T. Gerdes, J. Maahr, H. Rose, M. Bentz and H. Döohner, Deletions below 10 megabasepairs are detected in comparative genomic hybridization by standard reference intervals, Genes Chromosomes Cancer 25 (1999), 410-413.

[14] M. Kirchhoff, T. Gerdes, H. Rose, J. Maahr, A.M. Ottesen and C. Lundsteen, Detection of chromosomal gains and losses in comparative genomic hybridization analysis based on standard reference intervals, Cytometry 31 (1998), 163-173. 
[15] T. Knutsen, L.A. Mickley, T. Ried, E.D. Green, S. du Manoir, E. Schrock, M. Macville, Y. Ning, R. Robey, M. Polymeropoulos, R. Torres and T. Fojo, Cytogenetic and molecular characterization of random chromosomal rearrangements activating the drug resistance gene, MDR1/P-glycoprotein, in drugselected cell lines and patients with drug refractory ALL, Genes Chromosomes Cancer 23 (1998), 44-54.

[16] K. Kudoh, M. Takano, T. Koshikawa, M. Hirai, S. Yoshida, Y. Mano, K. Yamamoto, K. Ishii, T. Kita, Y. Kikuchi, I. Nagata, M. Miwa and K. Uchida, Gains of 1q21-q22 and 13q12q14 are potential indicators for resistance to cisplatin-based chemotherapy in ovarian cancer patients, Clin. Cancer Res. 5 (1999), 2526-2531.

[17] K. Lee, M.G. Belinsky, D.W. Bell, J.R. Testa and G.D Kruh, Isolation of MOAT-B, a widely expressed multidrug resistance-associated protein/canalicular multispecific organic anion transporter-related transporter, Cancer Res. 58 (1998), 2741-2747.

[18] B. Leyland-Jones, L.R. Kelland, K.R. Harrap and L.R. Hiorns, Genomic imbalances associated with acquired resistance to platinum analogues, Am. J. Pathol. 155 (1999), 77-84.

[19] P. Lichter, M. Bentz, S. Du Manoir and S. Joos, Comparative genomic hybridization, in: Human Chromosomes, Principles and Techniques, R.S. Verma and A. Babu, eds, McGraw-Hill, New York, 1995, pp. 191-210.

[20] F. Mitelman, ISCN: An International System for Human Cytogenetic Nomenclature, S. Karger, Basel, 1995.

[21] D. Nielsen and T. Skovsgaard, P-glycoprotein as multidrug transporter: a critical review of current multidrug resistant cell lines, Biochim. Biophys. Acta 1139 (1992), 169-183.

[22] P.H. Rao, J. Houldsworth, K. Dyomina, N.Z. Parsa, J.C. Cigudosa, D.C. Louie, L. Popplewell, K. Offit, S.C. Jhanwar and R.S. Chaganti, Chromosomal and gene amplification in diffuse large B-cell lymphoma, Blood 92 (1998), 234-240.

[23] P.H. Rooney, D.A. Stevenson, S. Marsh, P.G. Johnston, N.E. Haites, J. Cassidy and H.L. McLeod, Comparative genomic hybridization analysis of chromosomal alterations induced by the development of resistance to thymidylate synthase inhibitors, Cancer Res. 58 (1998), 5042-5045.

[24] S. Sabbioni, G. Barbanti-Brodano, C.M. Croce and M. Negrini, GOK: a gene at 11 p15 involved in rhabdomyosarcoma and rhabdoid tumor development, Cancer Res. 57 (1997), 44934497.

[25] P.V. Schoenlein, Molecular cytogenetics of multiple drug resistance, Cytotechnology 12 (1993), 63-89.

[26] S. Struski, P. Cornillet-Lefebvre, M. Doco-Fenzy, J. Dufer, E. Ulrich, L. Masson, N. Michel, N. Gruson and G. Potron, Cytogenetic characterization of chromosomal rearrangement in a human vinblastine-resistant CEM cell line: use of comparative genomic hybridization and fluorescence in situ hybridization, Cancer Genet. Cytogenet. 132 (2002), 51-54.

[27] S. Struski, M. Doco-Fenzy, A. Trussardi, L. Masson, N. Gruson, E. Ulrich, M. Proult, J.C. Jardillier, G. Potron and P. Cornillet-Lefebvre, Identification of chromosomal loci associated with non-P-glycoprotein-mediated multidrug resistance to topoisomerase II inhibitor in lung adenocarcinoma cell line by comparative genomic hybridization, Genes Chromosomes Cancer 30 (2001), 136-142.

[28] J.R. Teyssier, J. Bénard, D. Ferre, J. Da Silva and L. Renaud, Drug-related chromosomal changes in chemoresistant human ovarian carcinoma cells, Cancer Genet. Cytogenet. 39 (1989), $35-43$.

[29] J.R. Teyssier, P. Couillin, J. Bénard, N. Ravisse, E. Ulrich and P. Cornillet, A multidrug-resistant ovarian carcinoma cell line with a malignant suppressed phenotype is a CD44 gene expression defective mutant, Cancer Genet. Cytogenet. 60 (1992), $14-19$.

[30] V.M. Wasenius, A. Jekunen, O. Monni, H. Joensuu, S. Aebi, S.B. Howell and S. Knuutila, Comparative genomic hybridization analysis of chromosomal changes occurring during development of acquired resistance to cisplatin in human ovarian carcinoma cells, Genes Chromosomes Cancer 18 (1997), 286291. 


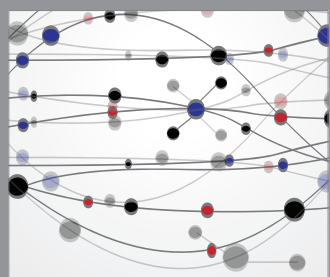

The Scientific World Journal
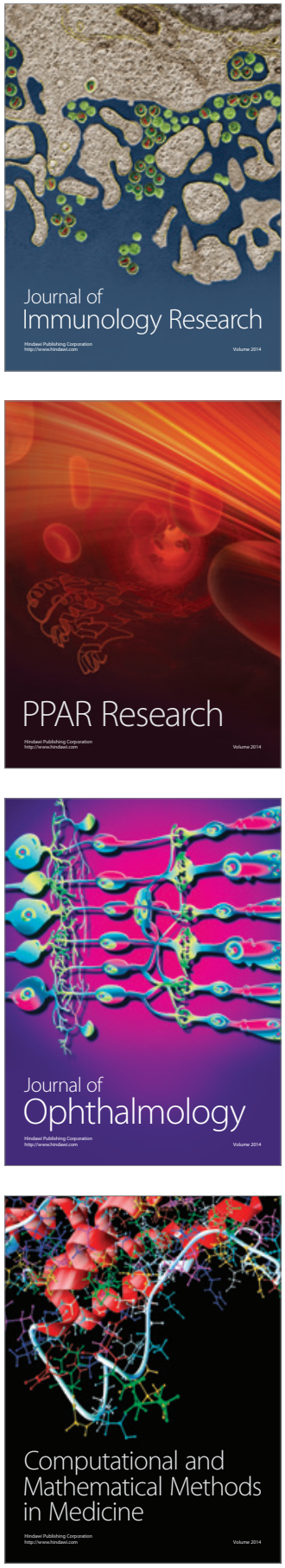

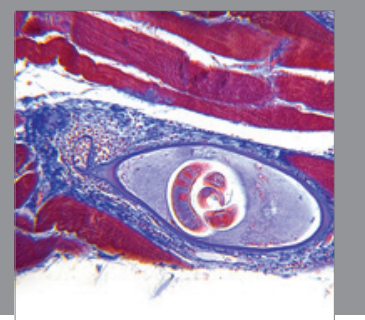

Gastroenterology

Research and Practice
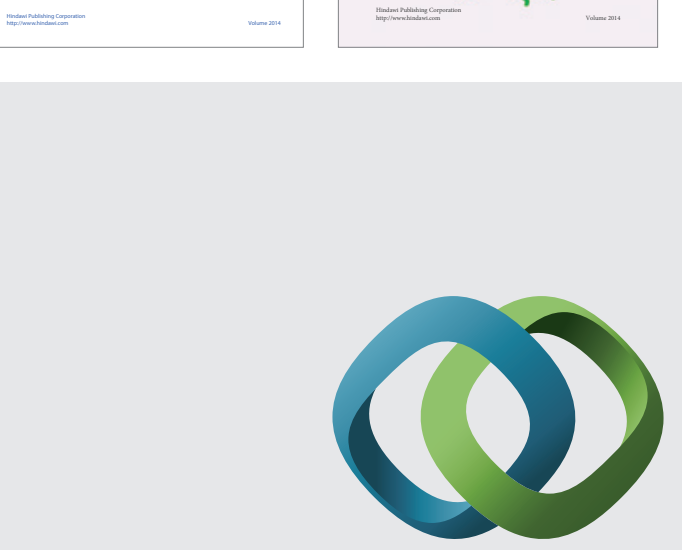

\section{Hindawi}

Submit your manuscripts at

http://www.hindawi.com
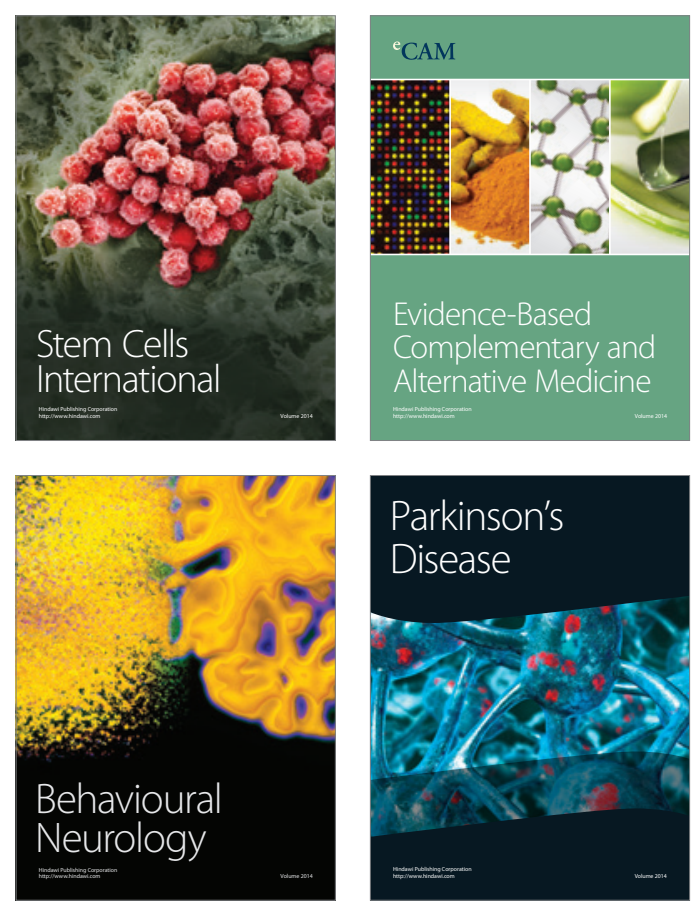

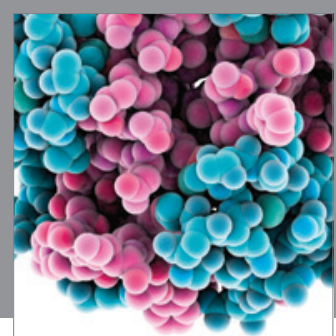

Journal of
Diabetes Research

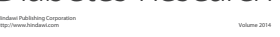

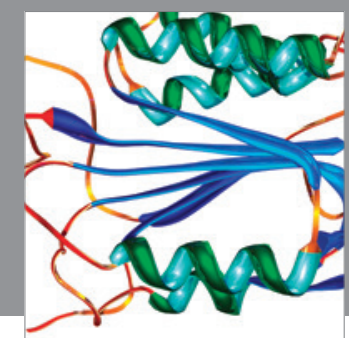

Disease Markers
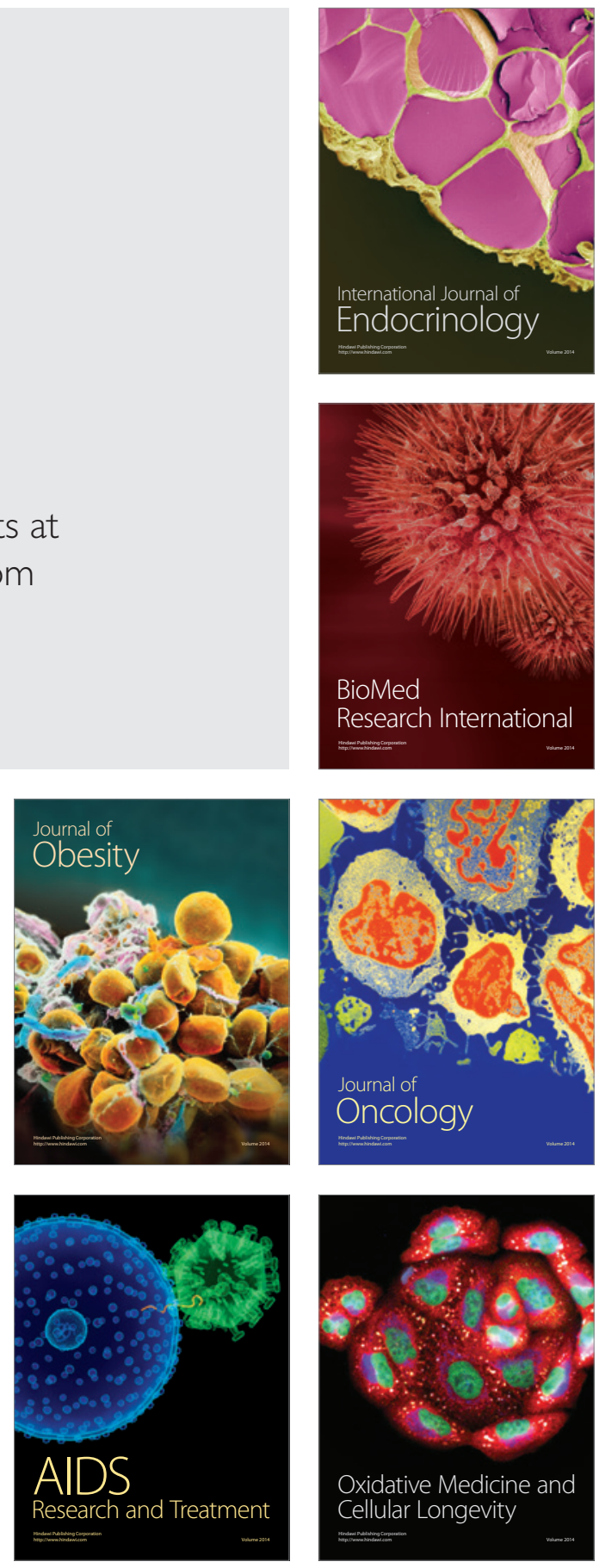